Article

\title{
Cumulative Pressures on Sustainable Livelihoods: Coastal Adaptation in the Mekong Delta
}

\author{
Timothy F. Smith ${ }^{1, *}$, Dana C. Thomsen ${ }^{1}$, Steve Gould ${ }^{1}$, Klaus Schmitt ${ }^{2}$ and Bianca Schlegel ${ }^{2}$ \\ 1 Sustainability Research Centre, University of the Sunshine Coast, Maroochydore DC 4558, \\ Australia; E-Mails: dthomsen@usc.edu.au (D.C.T.); sgould1@usc.edu.au (S.G.) \\ 2 Deutsche Gesellschaft für Internationale Zusammenarbeit (GIZ), Soc Trang Province, Vietnam; \\ E-Mails: klaus.schmitt@giz.de (K.S.); bianca.schlegel@giz.de (B.S.) \\ * Author to whom correspondence should be addressed; E-Mail: tsmith5@usc.edu.au; \\ Tel.: +61-7-5459-4891; Fax: +61-7-5456-5008.
}

Received: 9 November 2012; in revised form: 11 January 2013 / Accepted: 14 January 2013 / Published: 17 January 2013

\begin{abstract}
Many coastal areas throughout the world are at risk from sea level rise and the increased intensity of extreme events such as storm surge and flooding. Simultaneously, many areas are also experiencing significant socio-economic challenges associated with rural-urban transitions, population growth, and increased consumption resulting from improving gross regional product. Within this context we explore the viability of proposed adaptation pathways in Soc Trang province, Vietnam - an area of the Mekong Delta experiencing cumulative pressures on coastal livelihoods. A participatory workshop and interviews, using a combination of systems thinking and futures techniques, revealed a shared goal of sustainable livelihoods, which provides an integrated and systemic focus for coastal adaptation strategies. Emphasizing sustainable livelihoods is less likely to lead to maladaptation because stakeholders consciously seek to avoid optimizing particular system elements at the expense of others - and thus engage in broader decision-making frameworks supportive of social-ecological resilience. However, the broad ambit required for sustainable livelihoods is not supported by governance frameworks that have focused on protective strategies (e.g., dyke building, strengthening and raising, to continue and expand agriculture and aquaculture production) at the expense of developing a diverse suite of adaptation strategies, which may lead to path dependencies and an ultimate reduction in adaptive capacity for system transformation.
\end{abstract}

Keywords: coastal livelihoods; adaptation; adaptive capacity; Mekong; Vietnam 


\section{Introduction}

The resilience of socio-ecological systems is increasingly tested through the combined impacts of climate change and patterns of development associated with population growth and economic development [1]. These impacts are manifested in various forms such as sea level rise; increased intensity of extreme events such as storm surge and flooding; rural-urban transitions; population growth; and increased consumption resulting from improving gross regional product. Recognition that climate change mitigation efforts, while critical, will be insufficient to ensure community resilience has prompted an increased focus on the facilitation of adaptive responses to the dynamics experienced within socio-ecological systems [2].

We explore adaptation through the lens of the cumulative pressures affecting (or likely to affect) the Mekong Delta by describing the adaptation challenges in Soc Trang Province, Vietnam, in terms of both socio-economic and bio-physical trends and projections. The findings of a participatory systems and futures workshop, combined with key informant interviews, are then used to critically analyze a unifying adaptation framework based on sustainable livelihoods, whose utility is potentially limited by system complexity, protection-focused governance frameworks, and capacity challenges. Conclusions are drawn in relation to systemic governance adaptations to enable transformation towards sustainable livelihoods in the Mekong Delta.

\section{Soc Trang: A Context of Cumulative Adaptation Challenges}

Soc Trang is located in the Mekong Delta, Vietnam. The province faces significant adaptation challenges due to rapid changes in population and patterns of development, production, and consumption that combine to increase the relative vulnerability to the impacts of climate change.

Although the rate of population increase has slowed over recent years-from 2005 to 2011 the population of Soc Trang province increased by 45,089 people (3.58\% increase over 6 years) to a total population of over 1.3 million people and a population density of 394 people per sq $\mathrm{km}$. The total area of the province is $3,311 \mathrm{sq} \mathrm{km}$ and is dominated by agricultural land uses ( $84 \%$ of land is used for agricultural purposes-mainly for rice and, to a lesser extent, aquaculture production) [3]. However, Soc Trang is rapidly urbanizing with a 50\% increase in urban dwellers between 1992 and 2011 , such that over $29 \%$ of the population of the province now resides in urban areas. The trend towards urbanization has led to an increase in urban-based economic activity and associated infrastructure. For example, manufacturing, trades and construction now account for over $20 \%$ of the workforce and other urban-based sectors are also on the rise such as financial and scientific sectors. The relative contribution of various sectors to Gross Regional Product (GRP) is also changing - the agricultural sector continues to dominate GRP but with a reduced relative contribution [3] (Table 1).

In addition to rapid socio-economic change, Soc Trang is also experiencing significant changes to ecological systems that will be further exacerbated by the continued impacts of climate change and development. For example, the Mekong Delta is already highly susceptible to flooding, with $75 \%$ of Vietnam's areas at risk located in the Mekong Delta [4]. The impact of this on communities is demonstrated by the devastating floods of 2000 and 2001 that resulted in 481 and 393 fatalities respectively [4]. Similarly, the 2006 Integrated Coastal Zone Management strategy for Vietnam 
developed by the Ministry of Natural Resources and Environment [5], identified an over-exploitation of wild fish stocks that may be accentuated by climate change through the altered abundance and distribution of fish species.

Table 1. Contributions to GRP (in VND) of various sectors in Soc Trang from 1992 to 2011 (1 US Dollar currently equals approximately 20,850 VND).

\begin{tabular}{ccccc}
\hline Year & $\begin{array}{c}\text { Agriculture, forestry } \\
\text { and fishing }\end{array}$ & $\begin{array}{c}\text { Industry and } \\
\text { construction }\end{array}$ & Services & Total \\
\hline \multirow{2}{*}{1992} & $1,699,051$ & 459,456 & 453,752 & $2,612,259$ \\
& $(65 \%)$ & $(18 \%)$ & $(17 \%)$ & \\
2010 & $38,083,936$ & $26,775,347$ & $16,893,785$ & $81,753,068$ \\
\hline
\end{tabular}

Some of the climate change exposure changes projected for the province include sea level rise, increased temperatures, and more extreme events. Sea level rise is projected to increase between $30 \mathrm{~cm}$ and $75 \mathrm{~cm}$ by 2100 [6]. Indeed, the Mekong Delta has been cited as extremely vulnerable to sea-level rise [7]. Temperatures are projected to increase between $2.5^{\circ} \mathrm{C}$ and $2.8^{\circ} \mathrm{C}$ by 2100 [4], which may affect crop yields and also human health (e.g., through the increased potential for vector-borne disease such as malaria and dengue). Daily rainfall is projected to increase between $12 \%$ and $19 \%$ by 2070 [8], which will increase the likelihood of extreme flood events. However, while there will be periods of more intense rainfall during the rainy season, there will also be periods of more prolonged drought during the dry season [9].

Dasgupta et al. [10] state that a $1 \mathrm{~m}$ rise in sea level would affect $5 \%$ of the land area of Vietnam, $11 \%$ of the population, and reduce Gross Domestic Product by $10 \%$. However, the potential for the uneven impact of climate change on communities is highlighted by Chaudhry and Ruysschaert [4] who conclude that the rural poor will be most affected due to their reliance on agriculture, aquaculture, and fisheries for their income and food security. Furthermore, while there is increasing financial wealth in Soc Trang (GRP has increased from 2.6 million VND per person in 1995 to 20.4 million VND per person in 2010), this may not necessarily translate into the broad-scale resources needed for climate change response. Adger [11] observed that climate change response in the Red River Delta was restricted by the concentration of wealth and capital among a small proportion of the population.

Current efforts to reduce the impacts of sea level rise and storm surge encompass a number of initiatives including dyke construction and mangrove restoration (see for example [12,13]). Future efforts are likely to be directed by the "Master Plan on Socio-economic Development of Soc Trang Province through 2020" [13] approved by the Vietnamese government in April 2012. The Master Plan considers economic development, social progress and justice, human resource development, and the need to be proactive in limiting the impacts of climate change. Specific reference is made to integrated coastal management and sea level rise. It includes four development objectives: (i) development of sustainable hi-tech agriculture (in conjunction with industrial and service development); (ii) development of the provincial infrastructure system; (iii) improvement in the 
material and spiritual wealth of communities; and (iv) consolidated defense and security measures to assure social order.

More detailed development objectives include a reduced reliance on agriculture towards growth in the services sectors (Table 2). Nevertheless, the Master Plan [13] still refers to the intensification and growth of the agriculture, forestry and fishing sectors through the development of specialty rice varieties for export, vegetables, and aquaculture products to increase these outputs by $4.2 \%$ per annum (the desired growth in the services sectors is up to $16 \%$ per annum). In terms of aquaculture in particular, there is reference to: expansion of farms in saline, brackish and freshwater areas; improved infrastructure; the application of biotechnology and advanced technical processes; and the expansion of the total area under aquaculture from 54,518 ha in 2010 [3] to 80,000 ha (including 49,000 ha for shrimp) by 2015 and up to 85,000 ha by 2020 [13]. Similarly, the Master Plan contains expansion of the output and efficiency of the offshore fishing fleet, incorporating the construction of fish ports. Marine and cultural tourism is also proposed to "make tourism a spearhead industry in international economic integration" [13].

Table 2. Projected changes to the contributions to GRP of various sectors in Soc Trang from 2010 levels to 2015 and 2030.

\begin{tabular}{ccccc}
\hline Year & $\begin{array}{c}\text { Agriculture, } \\
\text { forestry and fishing }\end{array}$ & $\begin{array}{c}\text { Industry and } \\
\text { construction }\end{array}$ & Services & $\begin{array}{c}\text { Average income } \\
\text { per capita }\end{array}$ \\
\hline 2010 & $52 \%$ & $27 \%$ & $21 \%$ & USD 1,066 \\
2015 & $40 \%$ & $25 \%$ & $35 \%$ & USD 1,800 \\
2030 & $28 \%$ & $34 \%$ & $38 \%$ & USD 3,300 \\
\hline
\end{tabular}

The Master Plan also describes a number of other objectives supportive of adaptation and sustainability generally, including a reduction in poverty levels, improved levels of education and health, increased forest coverage (mainly for timber production), and the collection and treatment of solid and industrial waste [13]. With regard to coastal infrastructure, apart from mentioning re-settlement plans, there is a strong emphasis on protective strategies with several prioritized projects for the province relating to the upgrading or construction of sea dykes (4 major dyke projects identified) [13].

\section{Research Approach}

The research approach used a mixed-method of desktop review, participatory systems and futures workshop, and key informant interviews (Figure 1). Complexity, uncertainty and high decision stakes categorize coastal management in the face of climate change [14]. A systems and futures workshop was used in this study to: (i) unpack complexity; (ii) identify plausible futures; and (iii) develop strategies to address the key concerns of sectors and communities over multiple time scales. Following these, key informant interviews enabled the identification and verification of perceived adaptive capacity importance and existence in the province.

The workshop and interviews with Soc Trang stakeholders, mediated through Deutsche Gesellschaft für Internationale Zusammenarbeit (GIZ), comprised a cross-section of coastal stakeholder interests, including government agencies, NGOs, district representatives, and industry 
representatives (e.g., aquaculture and agriculture) and generated substantive contributions to the research. The workshop and interviews also engaged stakeholders with diverse interests in a multi-stage dialogue to facilitate adaptive learning for individual and collective action to build community response capacity.

Figure 1. Research stages.

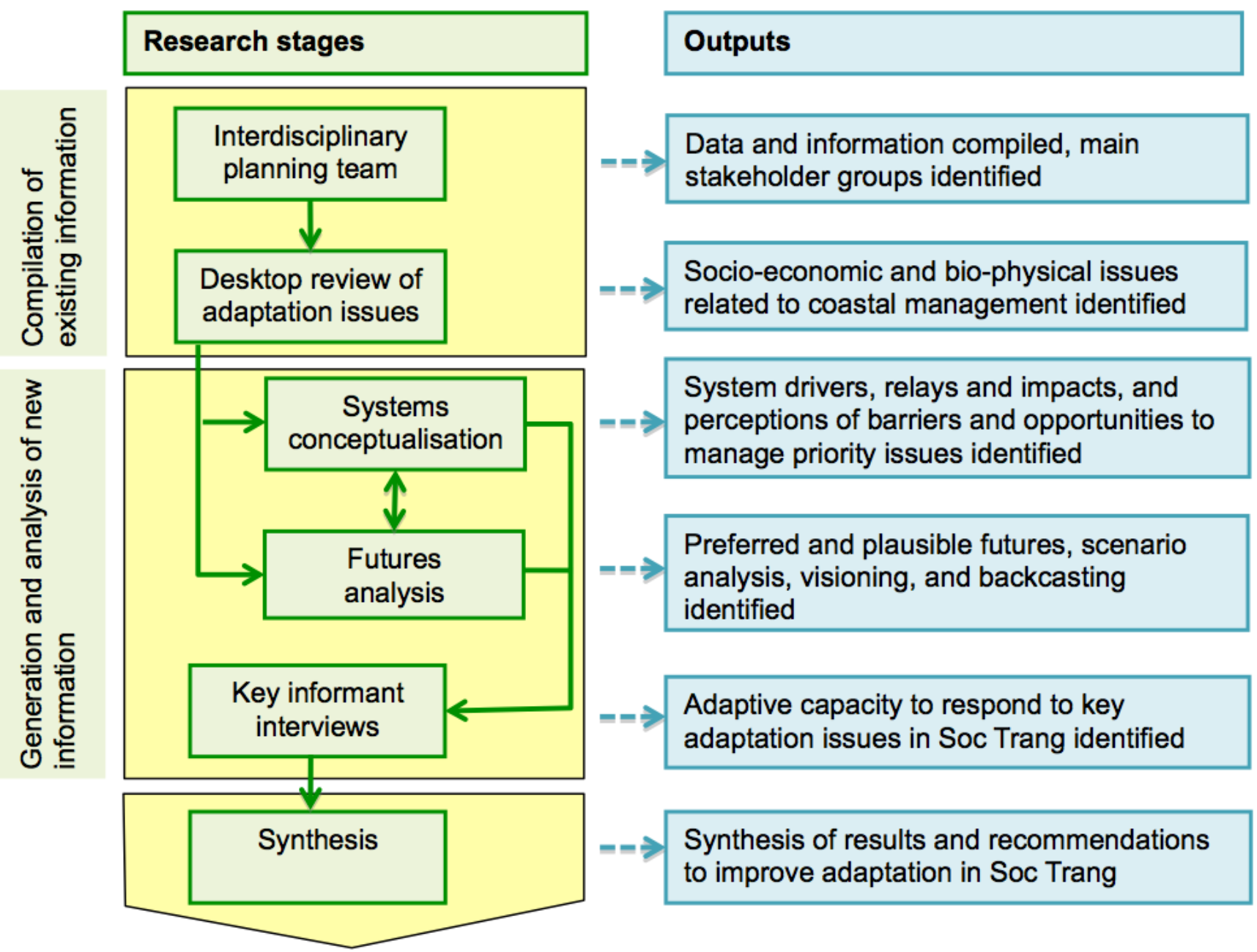

The methods were based on those used in several other studies focused on coastal management and climate change adaptation (see for example [15-20]). While beyond the scope of this research, additional community engagement mechanisms could be employed to target the acceptance and potential utility of specific adaptation options.

\subsection{Systems Conceptualisation}

Systems conceptualisation is a way of expressing and understanding the interdependencies and complexities inherent within coastal adaptation. It can facilitate the identification of the root causes affecting sustainability (drivers), the factors that may exaggerate or dampen the effects on sustainability (relays), and the effects themselves (impacts) [21]. By using a systems approach, communities are better placed to understand the likely consequences of their actions on sustainability (and their flow-on effects) and to make informed judgments about when and where to make effective 
interventions. Systems thinking approaches are increasingly being used in sustainability studies, including another recent study in Cat Ba Biosphere Reserve in northern Vietnam [22].

Co-development of a systems diagram among various Soc Trang stakeholders was stimulated by presenting some of the key issues affecting Soc Trang and engaging participants in an interactive session based on a series of maps, which detailed changes in landuse over time, current and planned infrastructure, and changes to the shoreline. Visualization of changes helps to assess the potential performance, implications and social acceptability of various adaptation strategies [23]. Stakeholders were then guided through a facilitated discussion that led to the development of a shared mental model (systems diagram) that captured the perceptions of key drivers of change, relays, and resulting impacts. Issues and linkages were captured simultaneously in English and Vietnamese using the software package, Vensim.

Sector groups then identified one priority issue to interrogate in relation to: (i) their current capacity to manage the issue; (ii) barriers to managing the issue; and (iii) future opportunities for management.

\subsection{Futures Analysis}

The conduct of the futures component of the workshop used the "six pillars" approach of futures studies [24] to transition stakeholders' perceptions from predicting or forecasting the future through anticipating the future to co-creating preferred futures. Stakeholders were engaged in a stepwise process that used the following tools of futures studies: futures triangle (an analysis of the pull of the future, the push of the present, and the weight of the past); scenarios (the creation of alternative and plausible ideas of the future); visioning (development of preferred visions of the future); and, backcasting (identification of the key events, relationships, and decisions necessary to achieve preferred futures) [24]. Throughout these steps, the "foundational futures questions" [24] were used to encourage stakeholders to critique and question assumptions regarding forecasted and preferred futures.

\subsection{Key Informant Interviews}

The perceptions of barriers and opportunities (systems conceptualization) and collective images of preferred coastal management futures (futures analysis) were used to inform key informant interviews that explored capacity issues using a capitals framework. While there are numerous interpretations of the types of capitals relevant to adaptive capacity (see for example [25-28]), for the purposes of this project, a 6-capitals framework was adopted that included: (i) human capital (e.g., skills, knowledge and experience of people); (ii) social capital (e.g., the functional relationships that exist between people); (iii) financial capital (e.g., the financial resources that can be utilized for adaptation); (iv) built capital (e.g., infrastructure and other built assets); (v) organizational capital (e.g., the organizational attributes needed for adaptation); and (vi) natural capital (e.g., the extent and condition of natural assets).

Ten key informant interviews were conducted with representatives from key stakeholder groups in Soc Trang (e.g., various district representatives and government agency senior staff such as the Department of Planning and Investment, Department of Culture Sports and Tourism, Department of Natural Resources and Environment, and the Provincial People's Committee). The interviews were semi-structured with a combination of closed and open-ended questions that were analyzed 
qualitatively for emerging themes and quantitatively for ratings of each of the 6 capitals. The 6 capitals were rated in terms of: (i) the importance for coastal management in Soc Trang; (ii) the extent of each capital within their organization or sphere of influence; and (iii) the extent of each capital within Soc Trang province.

\section{Results and Discussion}

\subsection{Sustainable Livelihoods as a Unifying Adaptation Framework}

A common approach to developing adaptation strategies is to follow a drivers-pressures-stateimpact-response (DPSIR) approach to identify actual or potential harm for an issue, community, sector or region, and mechanisms to reduce or negate it [29]. However, without a vision of a preferred future or a unifying values framework, individual adaptation options may be developed in isolation with inconsistent strategies that may lead to adaptation conflicts, maladaptations, or path dependencies. In addition, as Ellyard [30] states "lessening an undesirable outcome is not the same as creating a desirable outcome". Hence, one of the challenges of adaptation is the identification of preferred visions for the future that are either shared or compatible among stakeholders with diverse interests.

In this study, there was consensus among workshop participants regarding sustainable livelihoods as the preferred and overarching vision for the future. Definitions of sustainable livelihoods were also shared and comprised characteristics relating to natural resource conservation, knowledge development, and ensuring social equity. The focus on sustainable livelihoods provides: (i) a broad contextual framework that allows evaluation of all dimensions of sustainability; (ii) an opportunity to develop adaptation strategies cognizant of drivers and impacts at the system scale; and (iii) a rationale for all sectors within the system to contribute to the development of adaptation strategies towards the integration of diverse needs and aspirations. Scoones [31] identifies three main livelihood strategies for adaptation pathways for rural communities - these include: agricultural intensification/extensification; livelihood diversification; and migration to less vulnerable areas. The acceptance by all workshop participants and interviewees of the central role of education, awareness raising, and capacity building in achieving this, also allows communities to proceed to self-determination of where and how to apply these tools for maximum effect. In particular, the systems conceptualization and key informant interviews, conducted through this study, indicate that these strategies will need to be developed concurrently with mechanisms to build human and social capital within the province more generally. Stakeholders identified that this is partially being addressed through international donor support.

Consensus on the higher-level vision of sustainable livelihoods does not preclude the development of a diverse range of localized adaptation strategies. Diverse, but complementary, strategies can lead to more sustainable outcomes at local and regional levels in the longer term [31]. For example, diversified strategies offer greater opportunities for switching between strategies and ensuring less dependence on any one strategy across a range of socio-ecological dynamics and extended time frames. In addition, comprehensive assessment of the sustainability of particular strategies, across spatial and temporal dimensions, can assist in the development of a portfolio of mechanisms to achieve community goals without creating negative path dependencies and limiting future options [31,32]. 
Finally, the focus on sustainable livelihoods facilitates dialogue and debate on core community values and goals, and provides a guide for future adaptation success in Soc Trang. However, there will be several challenges associated with the pathways to achieve that vision, which will be compounded by issues such as climate change.

\subsection{Complexity and Interdependency}

The systems approach highlighted the diverse interplay between variables related to coastal issues (78 connections identified) and indicates that isolated interventions may have unintended consequences. For example, over $70 \%$ of the 38 variables identified by workshop participants provided a relay function; whereby they were identified as potentially magnifying or dampening the impacts on one or more other variables [21]. Hence, interventions should not only target the key system drivers (i.e., storm surge and population growth) but also relays that affect a high number of other variables in the coastal zone system (i.e., poverty, urbanization, reduced harvest productivity, loss of land, infrastructure, and changes in agricultural structure). Similarly, feedback loops, which are self-reinforcing should also be targeted. However, the magnitude of impacts resulting from those drivers, relays, and feedback loops (and thus the magnitude of the success of an intervention) need to also be considered.

In addition, several priority issues were identified by various sectors including water resource management for agricultural and rural development; environmental conditions for aquaculture production; sea level rise and salinization; and public awareness. However, while there were several opportunities identified to manage these issues (e.g., international cooperation, consensus among the districts, support and interest from government, and increasing research), the perceived current capacity to manage the priority issues was only considered to be low or medium. Several barriers were identified to managing the priority issues but the barriers that applied to all priority issues included: (i) poverty/income/funds; (ii) public awareness/education; (iii) human capital; and (iv) insufficient monitoring. These barriers were also reinforced through the futures activities. Hence adaptation initiatives may have more impact on priorities for the province if they address these barriers.

The challenge of transitioning towards resilient socio-ecological systems is compounded by complex system interactions [33] and the overall effects of adaptation strategies "must be considered strategically and holistically" [34]. For example, in the case of climate change several authors have highlighted complexity as a defining feature (see for example [14,35]). As demonstrated in Soc Trang, multiple system interactions affect (and are affected by) the coastal zone. However, while understanding of system interactions is critical for informing holistic adaptation response, it will not necessarily lead to integrated adaptation outcomes.

\subsection{Capacity and Governance for Sustainable Livelihoods}

The success or failure of adaptation strategies depends on a number of factors. Of central concern is the notion of capacity to implement and respond to sustainability issues [1]. While there are numerous definitions of adaptive capacity, for the purposes of this paper, the definition adopted by the IPCC Fourth Assessment Report [2] is used as starting point. The definition adopted is: "Adaptive capacity is the ability of a system to evolve in order to accommodate climate changes or to expand the range of 
variability with which it can cope" [36,37]. Alternative definitions are similar in character but with nuances relating, for example, to "A combination of all the strengths and resources available within a community, society or organization that can reduce the level of risk, or the effects of a disaster" [38] and "(...) the set of resources available for adaptation, as well as the ability or capacity of that system to use these resources effectively in the pursuit of adaptation" [39]. In addition, Brooks et al. [39] and many other authors highlight that adaptive capacity also relates to system adjustments to both existing climate variability or to future climate conditions.

In order to assess adaptive capacity in Soc Trang a capitals framework was used. All six capitals (social, human, organizational, financial, built and natural) were identified as being of high importance (Figure 2). However, human and social capital were rated as being of the highest importance-this emphasizes the recognition among stakeholders that effective adaptation occurs through social processes. Different types of capacity building activities may be needed to either improve or maintain various capitals. For example, financial and built capital were identified as being lacking in Soc Trang and may require more systemic actions; whereas actions relating to social, human and organizational capital may require continued investment in approaches already proven to be successful.

Figure 2. Perceptions of the importance and existence of adaptive capacity ( 0 equals none and 5 equals maximum importance/capacity).

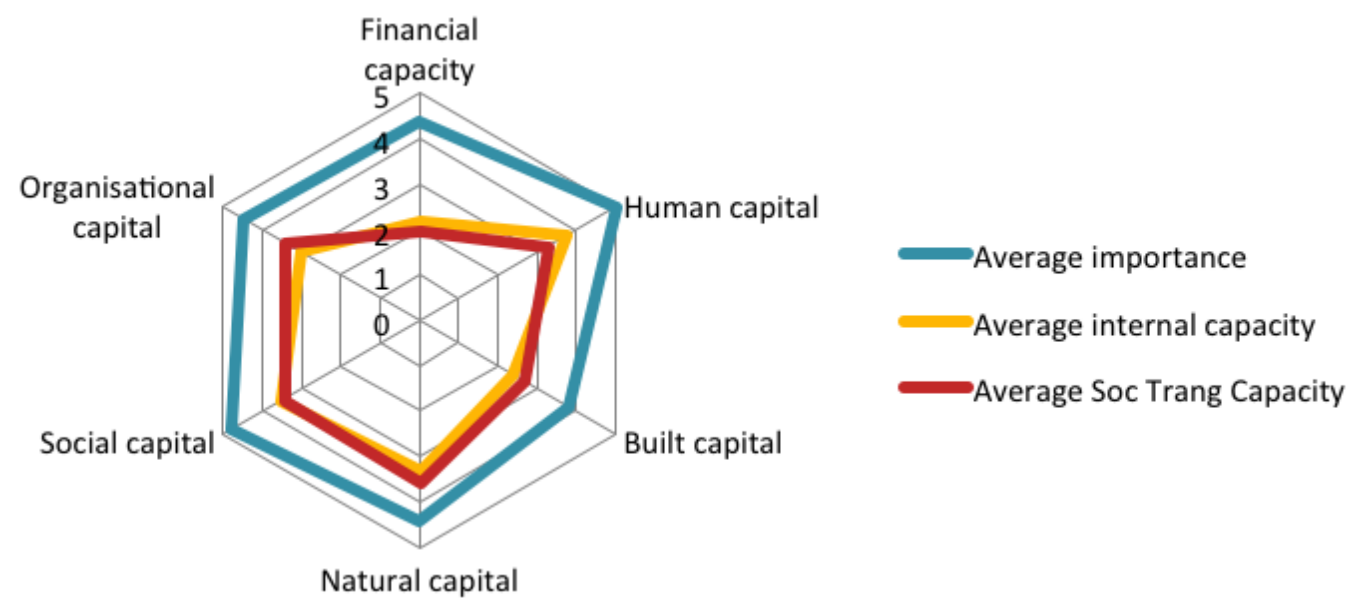

While there are bio-physical limits governing adaptation options (e.g., more intense rainfall events, shifts in the onset of the rainy season, increased temperatures, greater storm surge, and sea level rise), adaptation options are similarly limited by socio-economic conditions. For example, the rapid urbanization, and associated economic transformation, projected for Soc Trang over the next two decades (i.e., dramatic projected increase in the relative contribution of the services sectors to gross regional product) will influence the efficacy of particular adaptation options and necessitate the generation of new and unanticipated adaptation strategies. This implies the need for governance of adaptation to be cognizant of the changing contexts in the province. However, the expansion of the aquaculture industry has the potential to limit the amount of financial capital available for adaptation within other sectors and thus the range of adaptation options available for the province as a whole. For example, it is likely that costly protection measures such as dykes will be needed to protect existing and new aquaculture farms and processing facilities from the multiple climate change impacts of storm 
surge, sea level rise, and flooding. Hence, a systemic view focused on long-term priorities, and the acknowledgement of socio-economic and bio-physical trends, is needed for informed investment decisions in the coastal zone.

Tourism is emphasised in the Soc Trang Master Plan for 2020 [13], however, it was not identified as part of the systems or futures workshop. Many other South East Asian countries have developed or are attempting to develop tourism as a stimulant for economic development. While tourism may have benefits such as attracting international investment, there may be a number of adverse impacts relating to social and cultural factors, and diversion of resources for tourism infrastructure. Whatever strategy is adopted for promoting "development" (in all forms) it must be cognizant of the direct and indirect consequences from these initiatives. In addition, more comprehensive strategies should include avenues for transition from one course of action to another through adaptive governance processes [40], which can be difficult once a course of action with path dependencies is embarked upon [32]. In addition, strategies may be considered where revenue from one pathway is used to build the necessary conditions to enable a future alternate pathway.

While a sustainable livelihood vision is the overarching value proposition among stakeholders, adaptation strategies may need to accommodate the potential for diverse transformation pathways to lessen the risk posed by system uncertainties. As such, adaptation strategies may change over time due to changes in bio-physical and socio-economic conditions and priorities. Hence, governance structures and processes, whilst grounded in the overarching vision of sustainable livelihoods, require mechanisms to facilitate community engagement and meet changing community needs.

\section{Conclusions}

Sea level rise, the increased intensity of extreme events, rural-urban transitions, population growth, and increased consumption, typify some of the cumulative challenges facing coastal areas such as Soc Trang. A combination of systems thinking and futures studies tools enabled a comprehensive understanding of the current contexts for coastal management in the province, including the identification of preferred futures of various sectors and communities, as well as the priority actions needed to achieve these. The findings of this study indicate consensus among stakeholders that sustainable livelihoods should form the overriding goal of coastal management. The Soc Trang Master Plan [13] identifies a range of initiatives that could support a broad range of adaptation strategies such as education and re-forestation. However, the current investment focus on protection strategies (e.g., dykes) to continue and expand agriculture and aquaculture production may lead to path dependencies and an ultimate reduction in adaptive capacity for system transformation. In addition, the efficacy of adaptation strategies may be limited by levels of adaptive capacity and adaptation governance mechanisms within the province. In particular, stakeholders highlighted the importance of social and human capital in responding to coastal issues despite recognizing the persistent and low levels of financial and built capital that exist in the province. Furthermore, stakeholder confirmation of the benefits of donor support in building social and human capital highlights that there are many opportunities to build on past and continuing donor efforts, while ensuring adequate capacity for self-determinism in adaptation processes. Over-reliance on donor support does not reflect a sustainable livelihoods approach, however there is a rationale for the sharing of global resources when addressing 
global-scale problems that have led to localized consequences. In conclusion, there are numerous challenges facing Soc Trang in relation to adaptation to socio-ecological change. A focus on sustainable livelihoods can provide a unifying framework for action, especially if combined with adaptive capacity advances and systemic governance approaches to ensure the efficacy of adaptation pathways towards sustainable livelihoods.

\section{Acknowledgments}

This project was funded by the Deutsche Gesellschaft für Internationale Zusammenarbeit (GIZ).

\section{Conflict of Interest}

The authors declare no conflict of interest.

\section{References}

1. Adger, W.N. Vulnerability. Global Environ. Change 2006, 16, 268-281.

2. Adger, W.N.; Agrawala, S.; Mirza, M.M.Q.; Conde, C.; O’Brien, K.; Pulhin, J.; Pulwarty, R.; Smit, B.; Takahashi, K. Assessment of Adaptation Practices, Options, Constraints and Capacity. In Climate Change 2007: Impacts, Adaptation and Vulnerability. Contribution of Working Group II to the Fourth Assessment Report of the Intergovernmental Panel on Climate Change; Parry, M.L., Canziani, O.F., Palutikof, J.P., van der Linden, P.J., Hanson, C.E., Eds.; Cambridge University Press: Cambridge, UK, 2007; pp. 717-743.

3. Soc Trang Statistics Office. Soc Trang Statistical Yearbook 2011; Statistical Publishing House: Soc Trang, Vietnam, 2012.

4. Chaudhry, P.; Ruysschaert, G. Climate Change and Human Development in Viet Nam: A case study for the Human Development Report 2007/2008; UNDP: Hanoi, Vietnam, 2007.

5. Ministry of Natural Resources and Environment. Vietnam's ICZM strategy 2020 and orientation up to 2030, Final Draft; Ministry of Natural Resources and Environment, Hanoi, 2006. Available online: www.scribd.com/doc/6609260/ICZM-in-VietnamStrategy-Orientation (accessed on 25 October 2012).

6. Ministry of Natural Resources and Environment. Climate Change, Sea Level Rise Scenarios for Viet Nam; Ministry of Natural Resources and Environment: Ha Noi, Viet Nam. 2009. URL http://www.preventionweb.net/files/11348_ClimateChangeSeaLevelScenariosforVi.pdf (accessed on 11 January 2013).

7. Nicholls, R.J.; Wong, P.P.; Burkett, V.R.; Codignotto, J.O.; Hay, J.E.; McLean, R.F.; Ragoonaden, S.; Woodroffe, C.D. Coastal Systems and Low-Lying Areas. In Climate Change 2007: Impacts, Adaptation and Vulnerability. Contribution of Working Group II to the Fourth Assessment Report of the Intergovernmental Panel on Climate Change; Parry, M.L., Canziani, O.F., Palutikof, J.P., van der Linden, P.J., Hanson, C.E., Eds.; Cambridge University Press: Cambridge, UK, 2007; pp. 315-356.

8. Ministry of Natural Resources and Environment. Viet Nam Initial National Communication Under the United Nations Framework Convention on Climate Change; Ministry of Natural 
Resources and Environment: Ha Noi, Viet Nam. 2003. Available online: http://unfccc.int/resource/docs/natc/vnmnc01.pdf (accessed on 25 October 2012).

9. Hoanh, C.T.; Guttman, H.; Droogers, P.; Aerts, J. Will we produce sufficient food under climate change? Mekong Basin (South-east Asia). In: Climate Change in Contrasting River Basins: Adaptation Strategies for Water, Food, and Environment; Aerts, J., Droogers, P., Eds.; CABI Publishing: Wallingford, UK, 2004; pp.157-180.

10. Dasgupta, S.; Laplante, B.; Meisner, C.; Wheeler, D.; Yan, J. The Impact of Sea Level Rise on Developing Countries: A Comparative Analysis; World Bank Policy Research Working Paper 4136. 2007; Available online: www.wds.worldbank.org/servlet/WDSContentServer/ WDSP/IB/2007/02/09/000016406_20070209161430/Rendered/PDF/wps4136.pdf (accessed on 25 October 2012).

11. Adger, W.N. Indicators of Social and Economic Vulnerability to Climate Change In Viet Nam; CSERGE Working Paper GEC 98-02; 2002. Available online: www.cserge.ac.uk/sites/default /files/gec_1998_02.pdf(accessed on 25 October 2012).

12. Powell, N.; Osbeck, M.; Bach Tan, S.; Canh Toan, V. World Resources Report Case Study. Mangrove Restoration and Rehabilitation for Climate Change Adaptation in Vietnam; World Resources Report: Washington, DC, USA, 2011. Available online: http://www.worldresourcesreport.org (accessed on 25 October 2012).

13. Vietnamese Government. Decision No. 423/QD-TTg of April 11, 2012, Approving the Master Plan on Socio-economic Development of Soc Trang Province through 2020; Vietnamese Government: Ha Noi, Vietnam, 2012.

14. Smith, T.F. Beyond Knowledge: A Neo-Research Approach to Climate Change Adaptation. In Climate Change Responses across Regional Australia: Social Learning and Adaptation; Martin, J., Rogers, M., Winter, C., Eds.; VURRN Press: Victoria, Australia, 2009; pp. 30-44.

15. Smith, T.F.; Brooke, C.; Preston, B.; Gorddard, R.; Abbs, D.; Mcinnes, K.; Withycombe, G. Managing for Climate Variability in the Sydney Region. J. Coast. Res. 2007, 50, 109-113.

16. Gidley, J.M.; Fien, J.F.; Smith, J.A.; Thomsen, D.C.; Smith, T.F. Participatory futures methods as social learning: Towards adaptability and resilience in climate-vulnerable communities. Env. Pol. Gov. 2010, 19, 427-440.

17. Smith, T.F.; Lynam, T.; Preston, B.L.; Matthews, J.; Carter, R.W.; Thomsen, D.C.; Carter, J.; Roiko, A.; Simpson, R.; Waterman, P.; et al. Towards enhancing adaptive capacity for climate change response in South East Queensland. Australas. J. Disast. Trauma. Stud. 2010, 2010-1; Available online: http://trauma.massey.ac.nz/issues/2010-1/tsmith.htm (accessed on 16 January 2013).

18. Measham, T.G.; Preston, B.L.; Smith, T.F.; Brooke, C.; Gorddard, R.; Withycombe, G.; Morrison, C. Adapting to climate change through local municipal planning: Barriers and challenges. Mitig. Adapt. Strat. Global. 2011, 16, 889-909.

19. Smith, T.F.; Daffara, P.; O'Toole, K.; Matthews, J.M.; Thomsen, D.C.; Inayatullah, S.; Fien, J.; Graymore, M. A method for building community resilience to climate change in emerging coastal cities. Futures 2011, 43, 673-679.

20. Keys, N.; Bussey, M.; Thomsen, D.C.; Lynam, T.; Smith, T.F. Building adaptive Capacity in South East Queensland. Australia. Reg. Environ. Change, 2012, in press. 
21. Godet, M. From Anticipation to Action: A Handbook of Strategic Prospecting; UNESCO Publishing: Paris, France, 1994.

22. Nguyen, N.C.; Bosch, O.J.H.; Manni, K.E. Creating "learning laboratories" for sustainable development in biospheres: A systems thinking approach. Syst. Res. Behav. Sci. 2011, 28, 51-62.

23. Barron, S.; Canete, G.; Carmichael, J.; Flanders, D.; Pond, E.; Sheppard, S.; Tatebe, K. A climate change adaptation planning process for low-lying communities vulnerable to sea level rise. Sustainability 2012, 4, 2176-2208.

24. Inayatullah, S. Six pillars: Futures thinking for transforming. Foresight 2008, 10, 4-21.

25. Bourdieu, P. The Forms of Capital. In The Handbook of Theory: Research for the Sociology of Education; Richardson, J.G., Ed.; Greenwood Press: New York, NY, USA, 1986; pp. 241-258.

26. Bebbington, A. Capitals and capabilities: A framework for analyzing peasant viability, rural livelihoods and poverty. World Dev. 1999, 27, 2021-2044.

27. Emery, M.; Flora, C. Spiraling-Up: Mapping community transformation with community capitals framework. Community Dev. 2006, 37, 19-35.

28. Nelson, R.; Kokic, P.; Crimp, S.; Martin, P.; Meinke, H.; Howden, S.M.; de Voil, P.; Nidumolu, U. The vulnerability of Australian rural communities to climate variability and change: Part II-Integrating impacts with adaptive capacity. Environ. Sci. Pol. 2010, 13, 18-27.

29. Holman, I.P.; Rounsevell, M.D.; Shackley, S.; Harrison, P.A.; Nicholls, R.J.; Berry, P.M.; Audsley, E. A regional, multi-sectoral and integrated assessment of the impacts of climate and socio-economic change in the UK. Climatic Change 2005, 71, 9-41.

30. Ellyard, P. Designing 2050: Imagining and building a global sustainable society. Int. J. Futures Stud. 2011, 15, 175-190.

31. Scoones, I. Sustainable Rural Livelihoods: A Framework for Analysis; IDS Working Paper 72; Institute of Development Studies: Brighton, UK, 1998.

32. Thomsen, D.C.; Smith, T.F.; Keys, N. Adaptation or manipulation? Unpacking climate change response strategies. Ecol. Soc. 2012, 17, 20. Available online: http://dx.doi.org/10.5751/ES04953-170320 (accessed on 5 November 2012).

33. Folke, C.; Carpenter, S.R.; Walker, B.; Scheffer, M.; Chapin, T.; Rockström, J. Resilience thinking: Integrating resilience, adaptability and transformability. Ecol. Soc. 2010, 15, 20.

34. Tonn, B.; Stiefel, D. The Race for evolutionary success. Sustainability 2012, 4, 1787-1805.

35. Ravetz, J.R. What is post-normal science? Futures 1999, 31, 647-653.

36. Jones, R.N. An environmental risk assessment/management framework for climate change impact assessments. Nat. Hazards 2001, 23, 197-230.

37. Yohe, G.; Tol, R.S.J. Indicators for social and economic coping capacity - moving toward a working definition of adaptive capacity. Global Environ. Chang. 2002, 12, 25-40.

38. UN/ISDR (Inter-Agency Secretariat of the International Strategy for Disaster Reduction). Living with Risk: A global review of disaster reduction initiatives (Volume II Annexes); United Nations: New York, NY, USA, 2004. Available online: www.unisdr.org/files/657_lwr21.pdf (accessed on 25 October 2012). 
39. Brooks, N.; Adger, W.N.; Barnett, J.; Woodward, A.; Lim, B. Assessing and Enhancing Adaptive Capacity. In Adaptation Policy Frameworks for Climate Change: Developing Strategies, Policies and Measures; Lim, B., Spanger-Siegfried, E., Burton, I., Malone, E., Huq, S., Eds.; Cambridge University Press: New York, NY, USA, 2005, pp. 165-181.

40. Folke, C.; Hahn, T.; Olsson, P.; Norberg, J. Adaptive governance of social-ecological systems. Annu. Rev. Environ. Resour. 2005, 30, 441-473.

(C) 2013 by the authors; licensee MDPI, Basel, Switzerland. This article is an open access article distributed under the terms and conditions of the Creative Commons Attribution license (http://creativecommons.org/licenses/by/3.0/). 